\title{
ARHIV KNJIŽNIČARSKE UDRUGE : OD PRIVATNOG DO JAVNO DOSTUPNOG IZVORA ZNANJA
}

\author{
LIBRARY ASSOCIATIONS' ARCHIVES: \\ FROM PRIVATE TO PUBLICLY AVAILABLE \\ SOURCES OF KNOWLEDGE
}

\begin{abstract}
Edita Bačić
Pravni fakultet u Splitu

edita.bacic@pravst.hr

\section{Mihaela Kovačić}

Sveučilišna knjižnica u Splitu

mihaela@svkst.hr
\end{abstract}

\author{
UDK / UDC \\ [02+061.2]:[005.92+930.25] \\ Pregledni rad / Review paper \\ Primljeno / Received: 10. 4. 2018. \\ Prihvaćeno / Accepted:12. 6. 2018.
}

\section{Sažetak}

Cilj. Ukazati na važnost i potrebu da regionalne knjižničarske udruge u Hrvatskoj kao privatni stvaratelji i imatelji arhivskog gradiva vode o njemu sustavnu i standardiziranu brigu bez obzira na vrstu nosioca informacije.

Metodologija. Propituju se teorijske postavke, zakonska regulativa i mogućnosti nadležnih državnih arhiva u odnosu na knjižničarske udruge. Kao model istraživanja dobre i loše prakse upravljanja arhivskim gradivo uzeto je gradivo Društva knjižničara u Splitu. Usto, procjenjuje se mogućnost da se osnovnom korpusu gradiva pridruže privatni arhivi/zbirke fizičkih osoba - članova knjižničarske udruge.

Vjesnik bibliotekara Hrvatske 61, 1(2018), 321-343

ISSN 0507-1925

(C) VBH 2018. 
Rezultati. Svrha objedinjavanja gradiva jest stvaranje što cjelovitije dokumentacije o djelovanju knjižničarske zajednice u određenom prostoru i vremenu. Preduvjet je za to detaljnije reguliranje upravljanja pripadajućim arhivskim gradivom kroz dokumente knjižničarske udruge. Potvrdu tih promišljanja nalazimo i u praksi međunarodne knjižničarske zajednice (American Library Association Archive, Chartered Institute of Library and Information Professionnals i Associazione Italiana Biblioteche).

Originalnost rada. Ukazuje se na to da je na putu prema stvaranju što cjelovitijeg arhiva knjižničarske zajednice, jedinstvenog ne u fizičkom smislu, već u tematskom obuhvatu gradiva kod različitih stvaratelja i imatelja, već sada potrebno sustavno i standardizirano dokumentiranje njezina djelovanja na lokalnoj i nacionalnoj razini. Pritom je poželjan partnerski i savjetodavni odnos s arhivističkom zajednicom.

Ključne riječi: arhivi knjižničarskih udruga, Društvo knjižničara u Splitu, privatno arhivsko gradivo, udruge građana i arhivske službe

\section{Abstract}

Purpose. This paper considers the importance of the archive material of associations as private creators and possessors, with a special emphasis on the archives of regional library associations in Croatia. Services are discussed in relation to library associations.

Approach. Theoretical assumptions, statutory framework and the capabilities of competent state archives are discussed in relation to library associations. The material of the Library Association in Split was considered as a model for the study of good and bad practices with respect to the management of archive material. In addition, the possibility of adding private archives/collections of private individuals - members of the library association - to the basic corpus of materials has been assessed.

Results. The purpose of the aforementioned unification of the material is to create documentation as comprehensive as possible on the activities of the library community in a specific space and time. According to the results of the study, a prerequisite to achieve this goal is a more detailed regulation of the management of related archive material through the documents of the library association. Therefore, the final aim of this paper is to point out the need for a systematic care of library associations for archive material, regardless of the type of information carrier. Confirmation of these considerations can also be seen in the practice of the international library association (American Library Association, Chartered Institute of Library and Information Professionals and Associazione Italiana Biblioteche).

Originality/value. In order to create better integrated archival material as the source of knowledge on the activities and the impact of the library community in society, there is the need a for a unique form of concepts, cooperation and coverage at the local and 
national level, preferably in a partnership and advisory relationship with the archivist community.

Keywords: citizens' associations and archive services, library associations and archive material, Library Association in Split, private archive material

\section{Uvod}

Iako je knjižničarskoj zajednici u Hrvatskoj važnost registraturnog i arhivskog gradiva, kao i problematika upravljanja njime, načelno dobro poznata već i po samom poslanju, praksa često donosi drukčija iskustva. Naime u pristupu problematici stvaranja i pohrane arhivskog gradiva knjižničarskih udruga u Hrvatskoj uočava se svojevrsna nesustavnost, a u knjižničarskoj stručnoj literaturi o tome gotovo da se i nije pisalo. Istovremeno je arhivistička struka u Hrvatskoj detaljno teorijski, a donekle i u praksi, razradila problematiku arhivskog gradiva udruga. ${ }^{1}$ Usto, organizacija obiju zajednica - arhivističke na lokalnoj razini putem Državnih arhiva (i Hrvatskog društva arhivista), a knjižničarske kroz regionalne udruge (i Hrvatsko knjižničarsko društvo), kao i višegodišnja suradnja AKM-zajednice u obradi i predstavljanju njima pripadajućih informacijskih objekata, dobra su osnova za mogući partnerski i savjetodavni odnos s ciljem sustavnog i standardiziranog dokumentiranja djelovanja knjižničarske zajednice u lokalnoj sredini i šire. Kao model na kojem će se propitivati problematika stvaranja sadržaja, pohrane i dostupnosti arhivskog gradiva uzet je autoricama dobro poznat arhiv jedne knjižničarske udruge - Društva knjižničara u Splitu (DKST). Metodologija rada zasniva se na tri elementa: (1) propitivanje zakonodavnih i teorijskih postavki arhivističke struke u Hrvatskoj u odnosu na privatni status arhivskoga gradiva udruga (i knjižničarskih) te pojedinaca općenito; (2) povijest djelovanja navedenog modela iskazana uvidom u izvorno i njemu dopunsko arhivsko gradivo i zbirke (ustanove, pojedince), analiza sadašnje i planirane strukture arhiva i njemu pridruženih izvora; (3) usporedba stanja istovrsnog gradiva modela i drugih knjižničarskih udruga u Hrvatskoj i svijetu (American Library Association Archives, Chartered Institute of Library and Information Professionnals i Associazione Italiana Biblioteche). Rezultati provedenog istraživanja razjasnili su nekoliko čimbenika koji su, u konačnici, uzrokovali to da primijenjeni mehanizmi stvaranja i pohrane gradiva zakažu. Posljedica je necjelovitost gradiva te nerazmjer obima i važnosti sačuvanih i izgubljenih podataka o djelovanju udruge, ali i mnogih njezinih članova. Stoga je svrha ovoga rada ukazati na činjenicu da se u skoroj budućnosti prema dokumentiranju rada knjižničarskih udruga i njihovih članova treba odrediti sustavno i

1 Lučić, M. Arhiv i nevladine neprofitne organizacije: nadzor nad udrugama i akvizicijska politika. // Arhivski vjesnik 46, 1(2003), str. 63-66. 
sveobuhvatno na lokalnoj i široj razini, uz poželjnu savjetodavnu pomoć arhivske struke. S obzirom na istovjetno poslanje te problematiku arhivskog gradiva modela i ostalih knjižničarskih udruga u Hrvatskoj, moguće je i na njih, u većini slučajeva, primijeniti usvojenu strukturu njegova stvaranja i čuvanja zamišljenu po načelu $5 \mathrm{~W}-$ Tko? Što? Kada? Gdje? Zašto? Usvajanjem strukture arhiva regionalnih udruga, s arhivom Hrvatskoga knjižničarskog društva (HKD) kao okosnicom, te njima srodnih dopunskih izvora, mogao bi nastati više ili manje cjelovit arhiv knjižničarske struke u Hrvatskoj od polovice 20. stoljeća do naših dana, jedinstven ne u fizičkom smislu, već u tematskom obuhvatu gradiva.

\section{Udruge (knjižničarske) u svjetlu arhivističkih standarda}

\subsection{Općenito o udrugama i arhivskom gradivu}

Pojam udruga u smislu Zakona o udrugama podrazumijeva „svaki oblik slobodnog i dobrovoljnog udruživanja više fizičkih, odnosno pravnih osoba koje se, radi zaštite njihovih probitaka ili zauzimanja za zaštitu ljudskih prava i sloboda, zaštitu okoliša i prirode i održivi razvoj, te za humanitarna, socijalna, kulturna, odgojno-obrazovna, znanstvena, sportska, zdravstvena, tehnička, informacijska, strukovna ili druga uvjerenja i ciljeve koji nisu u suprotnosti s Ustavom i zakonom, a bez namjere stjecanja dobiti ili drugih gospodarski procjenjivih koristi, podvrgavaju pravilima koja uređuju ustroj i djelovanje toga oblika udruživanja." ${ }^{2}$

Iz navedene odredbe vidljivo je da u zakonodavnom kontekstu nema posebnih razlika među udrugama u sadržajnom smislu, pa su tako i knjižničarska društva samo dio istog pravnog okvira. Zajednička im je odrednica udruživanje bez namjere stjecanja dobiti ili drugih gospodarski procjenjivih koristi. Takve udruge pripadaju krugu neprofitnih organizacija, dio su civilnog sektora i kao korektiv vlasti važne su za razvoj svakog društva. ${ }^{3} \mathrm{~S}$ ciljem ostvarivanja svoje izvorne misije vezane uz razvoj i zaštitu knjižničarske struke, danas se i knjižničarska udruženja sve više okreću široj društvenoj zajednici tražeći potporu za svoje djelovanje. To je usko vezano uz promijenjenu ulogu knjižnica u razvoju suvremenog društva i nove trendove u knjižničarskoj praksi. Knjižnice svojim ukupnim djelovanjem, posebno u suradnji s vanjskim partnerima, pružaju širok spektar usluga koje osiguravaju kulturni, društveni i ekonomski razvoj zajednice te poboljšavaju

\footnotetext{
2 Zakon o udrugama: pročišćeni tekst zakona: NN 74/14, 70/17. // Zakon.hr. [citirano: 2018-0605]. Dostupno na: https://www.zakon.hr/z/64/Zakon-o-udrugama.

3 Petrović, Z. Bez udruga nestao bi balans oko različitih ideja u društvu. // Udruga: časopis za predsjednice/ke udruga i ostale odgovorne osobe u udrugama 23 (2016), str. 9.
} 
kvalitetu života u njoj. ${ }^{4}$ Knjižnice i strukovna udruženja na taj način djeluju kao partneri državnim službama u rješavanju pitanja od općeg društvenog interesa, pogotovo u otvorenim društvima. Sukladno toj promijenjenoj ulozi knjižničarske struke, raste i njezina odgovornost za ukupni napredak šire društvene zajednice, pa stoga za knjižničarske udruge možemo reći da se i po svom poslanju mogu uspoređivati s ostalim udrugama građana. Iz rada udruga nastaje raznovrsno gradivo važno kako u njihovu redovitom i budućem poslovanju tako i kao dokument o djelovanju i utjecaju koji su imale u određenom vremenu i prostoru. Njihovu vrijednost kao vjerodostojnih svjedoka upravnih, kulturnih i intelektualnih aktivnosti koji odražavaju razvoj društava, oblikuju individualno i kolektivno pamćenje, pridonose razumijevanju prošlosti i dokumentiraju sadašnjost u svrhu uspješnijeg provođenja budućih aktivnosti, potvrđuje i Opća deklaracija o arhivima. Usto, Deklaracija nalaže odgovoran odnos u upravljanju arhivskim gradivom ne samo arhivistima već i građanima, javnoj upravi, vlasnicima i imateljima javnog ili privatnog arhivskog gradiva, kao i ostalim informacijskim stručnjacima. ${ }^{5}$

Stoga je Opća deklaracija o arhivima neupitno obvezujuća i za sve članove knjižničarskih udruga uključene u proces upravljanja pripadajućim arhivskim gradivom - od sadržaja i obrade prikupljenoga gradiva do njegove pohrane i korištenja. Budući da pristup toj problematici treba biti sustavan, standardiziran i sveobuhvatan, evo i nekoliko definicija osnovnih arhivističkih pojmova nužnih za njezino razumijevanje. Arhivsko je gradivo zapis ili dokument nastao djelovanjem pravnih ili fizičkih osoba (dakle i udruga) u obavljanju djelatnosti. Nastaje postupkom odabiranja iz registraturnoga gradiva na temelju utvrđenih propisa, a stvaratelji i imatelji privatnog arhivskog gradiva mogu biti fizičke i privatne pravne osobe sukladno odredbama Zakona o arhivskom gradivu i arhivima. Arhivsko je gradivo od trajnog značenja za kulturu, povijest i znanost, neovisno o mjestu i vremenu nastanka te obliku i tvarnom nosaču na kojem je sačuvano. ${ }^{6} \mathrm{~S}$ obzirom na temu ovoga rada, važno je podsjetiti na to da se u Hrvatskoj gradivo privatnih stvaratelja čuva u različitim ustanovama, bez pravila o tome gdje će se i kako pohraniti, dok odluka o tome često ovisi o sklonostima pojedinaca, okolnostima i sl. Nadalje, ukupnost arhivskog gradiva u Hrvatskoj - i javnog i privatnog, neovisno o tome

\footnotetext{
4 Vidi više o tome: Librarians as community partners: an outreach handbook / ed. C. Smallwood. Chicago: American Library Association, 2010. Str. 153-186.

5 Opća deklaracija o arhivima. [citirano: 2018-01-29]. Dostupno na: http://www.arhiv.hr/ Portals/0/Dokumenti/Statut/OP\%C4\%86A_DEKLARACIJA_O\%20ARHIVIMA_web. pdf?ver=2018-03-29-161544-913.

6 Navedeno prema: Zakon o arhivskom gradivu i arhivima: pročišćeni tekst zakona: NN 105/97, 64/00, 65/09, 125/11, 46/17. // Zakon.hr. [citirano: 2018-06-06]. Dostupno na: https://www.zakon. hr/z/373/Zakon-o-arhivskom-gradivu-i-arhivima.Vidi i: Zapisi nevladinih organizacija: zajedničko pamćenje : praktičan vodič u 60 pitanja / [prip. A. Le Goff ; prijevod Ž. Heđbeli]. Zagreb: Documenta - centar za suočavanje s prošlošću, 2006. Str. 20, 21.; Pravni okvir zaštite i obveze stvaratelja i imatelja arhivskog gradiva. // Stručni ispit za zaštitu i obradu arhivskog gradiva: priručnik. Zagreb: Hrvatski državni arhiv, 2010.
} 
nalazi li se u javnim arhivima ili izvan mreže državnih arhiva - čini nacionalnu arhivsku baštinu. Stoga je zadaća arhivske službe da kroz sustav državnih arhiva brine o cjelini gradiva te osigurava njegovu zaštitu i informacijsku cjelovitost. ${ }^{7}$

\subsection{Status arhiva udruga u Hrvatskoj od 1945. do danas}

U Hrvatskoj se, u svjetlu niza promjena društvenog i političkog sustava koje su uslijedile nakon 1945. te 1991., status arhivskog gradiva udruga, općenito, na posredan i neposredan način odrazio na nacionalnu arhivsku službu i zakonodavstvo/ propise u arhivskoj djelatnosti. Sukladno tomu, u Hrvatskoj je i pitanje vlasništva nad navedenim gradivom bilo različito definirano u različitim društveno-političkim uređenjima u razdoblju od 1949. do danas. Niz akata (zakona, uputstava, pravilnika, popisa) nastalih u prvom razdoblju u odnosu na arhivsko gradivo udruga navodi sljedeće pojmove: društveno vlasništvo, društvena organizacija, građansko-pravne osobe i građani. ${ }^{8}$ Od 1997. u Hrvatskoj je na snazi Zakon o arhivskom gradivu i arhivima koji, u odnosu na prethodni Zakon o zaštiti arhivske građe $i$ arhivima iz 1978., kao jednu od bitnih novosti uvodi pojmove državnog vlasništva, javnog i privatnog gradiva te privatnih pravnih i fizičkih osoba. Dakle prema važećem pravnom sustavu Republike Hrvatske udruge imaju status privatno-pravne osobe te su stvaratelji i imatelji privatnog arhivskog gradiva. ${ }^{9}$ Prema statističkim pokazateljima, od 1990-ih broj je udruga u Republici Hrvatskoj (RH) znatno uvećan, a stanje njima pripadajućeg arhivskog gradiva, ovisno o okolnostima, složeno. Za više od 50000 udruga registriranih u RH, ovisno o području na kojem djeluju, resursi - prostorni, ljudski i materijalni - njima nadležnog državnog arhiva, koji bi trebao pratiti kako dokumentiraju svoj rad i, općenito, razvijati odnos sa svim udrugama, još su uvijek nedostatni. Nadležni su državni arhivi u svom radu usmjereni na kategorizirane stvaratelje i imatelje - javne (pravosuđe i javne ustanove) i privatne, o čemu će biti nešto više riječi u slijedećem poglavlju. Nadalje, arhivisti su tijekom vremena spoznali kako mnoge udruge nisu svjesne da se kao stvaratelji i vlasnici arhivskog gradiva, ponekad i trajne vrijednosti, trebaju pridržavati odredbi Zakona o arhivima te, sukladno tomu, prvenstveno same

U Hrvatskoj, sukladno organizaciji arhivske službe i arhivskom zakonu, djeluje jedinstvena arhivska služba i jedna matična ustanova - Hrvatski državni arhiv (HDA). Ćosić, S. Predgovor. // Pregled arhivskih fondova i zbirki Republike Hrvatske. Sv. 1. / ur. J. Kolanović. Zagreb : Hrvatski državni arhiv, 2006. Str. XIII.

8 Slijed akata objavljenih u Narodnim novinama s tim u vezi od 1963. do 1989. vidi u: Heđbeli, Ž. Privatno arhivsko gradivo. // Arhivski vjesnik 44 (2001), str. 95.

9 Privatno arhivsko gradivo nastalo je djelovanjem privatnih pravnih i fizičkih osoba, ukoliko nije nastalo u obavljanju javnih ovlasti ili u obavljanju javne službe te ako nije u državnom vlasništvu. Vidi: Zakon o arhivskom gradivu i arhivima: pročišćeni tekst zakona: NN 105/97, 64/00, 65/09, 125/11, 46/17. // Zakon.hr. [citirano: 2018-06-06]. Dostupno na: https://www.zakon.hr/z/373/Zakon-o-arhivskom-gradivu-i-arhivima. 
skrbiti o njemu. ${ }^{10}$ Stoga javna arhivska služba te nedostatke nastoji prevladati i/ili ublažiti pružajući, sukladno svojim kapacitetima, savjetodavnu i stručnu pomoć te edukaciju ne samo navedenim već i ostalim stvarateljima, nadzirući uz to provođenje zakonskih obveza. ${ }^{11}$ Odstupanje od njih, kako nekad tako i danas, često ima za posljedicu gubitak i uništenje gradiva, što je slikovito opisano još 1960-ih:

„(...) arhivsko se gradivo uništava, prisvaja, veoma često loše smještava, nalazi se i po stanovima dužnosnika, a u pravilu je ili potpuno nesređeno ili neznatno sređeno, društvene i političke se organizacije osnivaju, reorganiziraju i likvidiraju, a da o tome nije obaviešten nadležni poviesni arhiv“. ${ }^{12}$

Pogledajmo sada, u odnosu na opisanu arhivističku praksu, status arhivskog gradiva knjižničarskih udruga.

\subsection{Status arhiva knjižničarskih udruga}

Prema prethodnom pojašnjenu pojma udruga, odnosno na Zakon o udrugama iz 2014. i 2017., knjižničarskoj su udruzi, uz privatne fizičke osobe, po statusu srodni sljedeći privatni stvaratelji/imatelji arhivskog gradiva: raznovrsne udruge, političke stranke, sindikati, vjerske ustanove, gospodarski subjekti, strana predstavništva i slično. Zbog brojnosti udruga, skrb o njima pripadajućem arhivskom gradivu vrlo je zahtjevna, te su stoga arhivisti, kao što je prethodno navedeno, uspostavili postupke njegova vrednovanja i kategorizacije. Tako je od 1987. godine Uputstvo o vrednovanju registraturne građe kao kriterij navodilo: društvenu ulogu i značenje stvaraoca, vrijeme i mjesto postanka, stupanj sačuvanosti i sadržajnu fizionomiju, unikatnost $\mathrm{i}$ autentičnost, reprezentativnost i posebne vrijednosti gradiva. Donošenjem novog arhivskog zakona 1997. navedeni je propis stavljen van snage te je od 2002. važeći Pravilnik o vrednovanju te postupku odabiranja $i$

10 Prema podacima koje navodi Heđbeli, u RH je registrirano oko 20000 udruga te više od 100 političkih stranaka i 700 sindikata. Hrvatski državni arhiv (HDA) je 2000. godine uputio dopis stvarateljima privatnog arhivskog gradiva (bivše i sadašnje parlamentarne stranke, dio udruga) tražeći podatke o arhivskom gradivu. Na dopis većina njih nije odgovorila ili je izjavila kako takvo gradivo ne posjeduju. Podsjetimo kako je još 2003. bilo predloženo osnivanje arhiva organizacija civilnog društva gdje bi se pohranjivalo gradivo nastalo njihovim djelovanjem tijekom 1990-ih. O istoj temi raspravljalo se 2006. u Zagrebu na okruglom stolu Zajedničko sjećanje u organizaciji Documente - Centra za suočavanje s prošlošću i Nacionalne zaklade za razvoj civilnog društva. Usp. Zajedničko sjećanje. // Documenta. [citirano: 2018-01-29]. Dostupno na: https:// www.documenta.hr/en/zajedni\%C4\%8Dko-sje\%C4\%87anje.html.

11 Prijedlog arhivista bio je da nadležna služba već pri registraciji udruge preporuči istoj obavijestiti nadležni državni arhiv o osnivanju ili/i o posjedovanju gradiva. Vidi: Upute za udruge stvaratelje arhivskog gradiva. [citirano: 2018-01-29]. Dostupno na: https://udruge.gov.hr/vijesti/ upute-za-udruge-stvaratelje-arhivskog-gradiva/975.

12 Preporuka o zaštiti i čuvanju arhivsko-registraturne grade u političkim i društvenim organizacijama (11. 12. 1961). Navedeno prema: Heđbeli, Ž. Privatno. Nav. dj. str. 97. 
izlučivanja arhivskoga gradiva stvaratelje razvrstao u skupine ovisno o značenju cjeline gradiva nastale njihovim djelovanjem. ${ }^{13}$ Tako primjerice prema Pravilniku o vrednovanju kategorizacija HDA ostavlja mnoge od udruga izvan zone interesa arhiva, a prvenstvo biva usmjerena na znanstvene i strukovne udruge s dugom tradicijom djelovanja i značajnim doprinosom hrvatskoj znanosti i kulturi. Među njima izdvajamo Maticu hrvatsku (1842.) kao najstariju strukovnu i kulturno-prosvjetnu udrugu te Hrvatsko knjižničarsko društvo (1940.) kao jedno od mlađih. ${ }^{14}$

Procjenjujući kako mnogi arhivi knjižničarskih udruga u Hrvatskoj, u većini slučajeva, sadrže elemente za vrednovanje navedene u Uputstvu (1987.), odnosno Pravilniku o vrednovanju (2002.), smatramo obvezom knjižničara da u odnosu prema pripadajućem im gradivu, u novim tehnološkim okolnostima, prateći suvremene tokove arhivističke, ali i knjižničarske struke, porade na mehanizmima koji će na sustavan, standardiziran i sveobuhvatan način pravovremeno spriječili gubitak te stvarati nove i bogatije sadržaje važne ne samo u dokumentiranju rada knjižničarske zajednice već i kao putokaza i korektiva njezina budućeg djelovanja na lokalnoj i nacionalnoj razini. Na to nas obvezuje knjižničarska etika, ali i već spomenute odredbe Opće deklaracije o arhivima. Evo ponešto o dobrim i lošim iskustvima stvaranja i pohrane arhivskog gradiva Društva knjižničara u Splitu (DKST).

\section{Model knjižničarske udruge - od analognog do digitalnog arhiva}

\subsection{Povijest}

Iako je povijesti DKST-a do sada prikazana, više ili manje cjelovito, u spomenicama HKD-a 2000. i DKST-a 2010., izvještajima stručnih glasila, stručnim radovima te jednom diplomskom i doktorskom radu, ovom prigodom donosimo ju u svrhu jasnijeg uvida u strukturu njoj pripadajućeg arhivskog gradiva kao primjera „mikroarhiva“.$^{15} \mathrm{Na}$ njemu će se u nastavku rada graditi ideja o mogućem „ma-

13 Vidi: Uputstvo o vrednovanju registraturne građe (NN 33/1987) i Pravilnik o vrednovanju te postupku odabiranja i izlučivanja arhivskoga gradiva (NN 90/2002). Napominjemo: vrednovanjem se procjenjuje vrijednost zapisa, utvrđuje rok čuvanja te određuje postupak po isteku roka, dok se kategorizacijom stvaratelji razvrstavaju u skupine ovisno o značenju cjeline gradiva. Prema Pravilniku evidencije koje vode državni arhivi uključuju sve stvaratelje javnoga i one privatnoga arhivskog gradiva za koje se procijeni da stvaraju arhivsko gradivo trajne vrijednosti. Kategorizaciju tih stvaratelja utvrđuje Hrvatsko arhivsko vijeće na prijedlog državnih arhiva za područje njihovih nadležnosti, razvrstavajući ih u tri kategorije. Nakon objave kategorizacije u službenim glasilima, arhivi stvarateljima izdaju rješenje o kategorizaciji. Vidi: Pravni okvir Nav. dj., str. 21, 22.

14 Lučić, M. Nav. dj., str. 57, 58.

15 Primjerice na izvanrednom diplomskom studiju knjižničarstva Odjela za informacijske znanosti Sveučilišta u Zadru djelovanje DKST-a bilo je tema diplomskog rada, o čemu vidi: Fistanić, B. Društvo bibliotekara Split. Zadar : [vlast. nakl.], 2011. 
kroarhivu“ knjižničarske udruge/struke u Hrvatskoj od polovice 20. stoljeća do danas. Uz mnoge sličnosti s ostalim knjižničarskim udrugama u Hrvatskoj, DKST ima specifičnosti koji su odraz društvenih, prostornih i ekonomskih čimbenika, ali i osobnosti pojedinih njegovih sudionika. Službeno osnovano 1950., Društvo je jedna od starijih hrvatskih knjižničarskih udruga koje u kontinuitetu djeluju do danas. Njegov „pretpovijesni“ period započinje pokušajem da na prostoru srednje Dalmacije 1930./1940. knjižničarska struka započne organizirano djelovati. O tome vremenu svjedoče dva dopunska izvora - arhivi tadašnje Gradske biblioteke i Društva bibliotekara Hrvatske te njegovi sudionici - knjižničar Dušan Manger (1870.-1940.), a potom Julije Grabovac (1915.-1990.) i Hrvoje Morović (1914.1982.). Iako neuspio, pokušaj Mangera da 1931., na inicijativu zagrebačke sekcije Društva bibliotekara Jugoslavije (DBJ), pridobije članstvo i organizira njegovu splitsku sekciju vrijedan je podatak o tadašnjoj svijesti knjižničarske zajednice na prostoru srednje Dalmacije. Nekoliko mjeseci kasnije, u studenom 1931., Manger sudjeluje na I. kongresu bibliotekara Jugoslavije, održanom u Zagrebu, kao jedini predstavnik knjižničara iz Primorske banovine, a uskoro i kao potpredsjednik DBJ-a. ${ }^{16}$ Kada se 1940. zagrebačka sekcija odvojila od DBJ-a i osnovalo Društvo bibliotekara Hrvatske (DBH), među njegovim prvim članovima nalazimo još jednog predstavnika iz Dalmacije - povjesničara Julija Grabovca, od 1938./1940. na službi u Sveučilišnoj biblioteci u Zagrebu. Nakon što je 1948. u toj knjižnici obnovljeno i djelovanje spomenute stručne udruge bibliotekara i knjižničara, ulažu se napori da se proširi mreža članova Društva diljem Hrvatske preko tzv. povjereništava. Ona se osnivaju u većim sredinama koje su imale knjižnicu značajnu za zajednicu određenog područja. U Splitu, a potom i srednjoj Dalmaciji, s osnivanjem novih vrsta knjižnica, uz one postojeće, oživljeno je 1949./1950. organizirano djelovanje knjižničarske struke na koju će stečena stručna iskustva i kontekst širi od lokalnog uskoro prenijeti Grabovac i Morović. Godine 1950. Hrvoje Morović, Mangerov „nasljednik“ u Gradskoj biblioteci, imenovan je prvim povjerenikom. ${ }^{17}$ Povećavanjem članstva u povjereništvima, ona tijekom vremena prerastaju u podružnice koje odlikuje veća samostalnost i viši stupanj složenosti rada. ${ }^{18}$ Značajne promjene u DBH-u nastupile su 1974., kada su usklađivanjem njegova organizacijskog ustroja prema Zakonu o udruženjima građana SR Hrvatske dotadašnje podružnice postale regionalna društva. Takav preustroj DBH-a,

16 Taj dio povijesti Društva dokumentiran je u arhivu Gradske biblioteke, danas Sveučilišne knjižnice u Splitu. Vidi: Anzulović, N. Iz pretpovijesti Hrvatskog knjižničarskog društva. // Glasnik Društva bibliotekara Split $=$ Spomenica 8 (2010), 9-15.

17 Bačić; E.; M. Kovačić; Ž. Siminiati Violić. Društvo knjižničara u Splitu: što smo bili i kamo idemo? // Vjesnik bibliotekara Hrvatske 58, 1/2 (2015), str. 244, 245.

18 O većem društvenom značaju splitske podružnice govori podatak kako je 1960-ih podržala potrebu Narodne biblioteke da osnuje nove gradske podružnice, a od NO Općine Split tražila je da se u Statutu Općine „odrede zadaci i položaj biblioteka“. Vidi: Arhiv DBST. Izvještaj Podružnice Split za god 1962. 
koji s regionalnim društvima čini savez, imao je za cilj omogućiti što većem broju članova sudjelovanje u radu društva u cjelini, a održao se do danas. ${ }^{19}$ Kratak pregled djelovanja DKST-a oslikava načine na koje se promjene u društvu od 1930-ih do danas odražavaju na funkcioniranje jedne knjižničarske udruge na području srednje Dalmacije, ali i odnos sa središnjicom - DBH-om/HKD-om. Pritom arhiva Društva kao karika u lancu višestoljetne tradicije javnog knjižničarstva i organiziranog djelovanja struke predstavlja izvor za buduću povijest razvoja knjižničarstva u Dalmaciji te zaslužuje posebnu brigu. Stoga pogledajmo u kojoj mjeri sačuvana sadržajna struktura pripadajućeg arhivskog gradiva prati navedeno.

\subsection{Sadržajna struktura, sređivanje i pohrana Arhiva}

Knjižničarska, ali i šira, javnost dosad je imala priliku steći uvid u veći dio sačuvanog arhivskog gradiva DKST-a i njemu dopunskih izvora prigodom prve obljetničke izložbe Društva 1999. te u izdanjima dviju spomenutih spomenica. Stvaranje arhiva Društva započelo je njegovim djelovanjem 1950., iako najstariji dokument s tim u vezi datira iz 1949. U skladu s ranije navedenim poretkom u Hrvatskoj, arhivsko gradivo nastalo radom Društva od 1950-ih imalo je status društvenog, a od 1990-ih privatnog gradiva. ${ }^{20}$ Važno je spomenuti kako je već u počecima djelovanja, obilježenim komunikacijskim ograničenjima na užem i širem području, poticaje za dokumentiranje svoga rada DKST mogao primiti iz dva izvora: knjižničarske i arhivističke zajednice. Naime DBH već u svojim prvim dokumentima - Pravilima - navodi „društvenu registraturu“, propisuje sadržaj i način dokumentiranja poslovanja te nadzor nad njim ,u svakom trenutku“. Tako je Društvo bilo dužno voditi urudžbeni zapisnik, knjigu zapisnika o sjednicama upravnog odbora, propisane blagajničke i sindikalne knjige, dok se jedan primjerak zapisnika o radu skupštine čuvao u društvenoj registraturi. $\mathrm{O}$ svemu navedenom, među ostalim, brinuo je Nadzorni odbor i, ovisno o zatečenom stanju, predlagao razrješnicu upravnom tijelu po isteku mandata. U slučaju prestanka postojanja DBH-a pokretna i nepokretna imovina, dakle i arhiva, trebala se predati na čuvanje upravi Sveučilišne knjižnice u Zagrebu do ponovnog osnivanja istog ili društva s istom ili sličnom svrhom, unutar pet godina. U protivnom, društvena bi

19 Vidi: Zakon o udruženjima građana SR Hrvatske. // Narodne novine 26 (1973).; Švenda Radeljak, K. Obrazovanje i status knjižničara u Hrvatskoj do uvođenja studija bibliotekarstva: doktorski rad. Zagreb : [vlast. nakl.], 2012. Str. 93.

${ }^{20}$ Kao pravna osoba DKST je vlasnik privatnoga arhivskoga gradiva kojim slobodno raspolaže te ne podliježe obvezi predaje u Državni arhiv Split (DAST). Do početka 1990-ih udruge se prijavljuju u Sekreterijat unutarnjih poslova / Sekreterijat za opću upravu, a danas u Registar udruga RH pri nadležnom tijelu državne uprave. Dakle relevantni dokumenti DKST-a (registracija, Statut i sl.) pohranjeni su kod tijela državne uprave.

Prema podacima objavljenim 2009. u Vodiču kroz arhivske fondove i zbirke DAST-a, među društvima, udrugama i udruženjima DKST nema srodnih knjižničarskih. 
imovina postala vlasništvo navedene ustanove. ${ }^{21}$ Kako se od 1950-ih u Hrvatskoj, usporedno s knjižničarskom, razvijala i moderna arhivistička služba, oblikovala mreža državnih arhiva i razvijalo zakonodavstvo, započela je i suradnja tih dviju zajednica. Ona se u Splitu primjerice ogledala u radu Savjeta za kulturu NO općine Split za koji su, prema tada važećim propisima, podružnice DBH-a i DAH-a zajedno birale svoje predstavnike. O stručnoj suradnji dviju zajednica 1964. godine svjedoči poziv Saveza Društava arhivista Jugoslavije splitskoj Podružnici da prisustvuje $V$. redovnoj skupštini i savjetovanju. ${ }^{22}$

Usvajajući od 1950-ih/1960-ih navedene obrasce i standarde dokumentiranja rada od obiju zajednica, Društvo knjižničara u Splitu ustrajava na stvaranju svoga arhiva. Prvi studiozniji uvid u ovo arhivsko gradivo obavljen je 1998., prigodom priprema za obilježavanje pet desetljeća djelovanja. Uvid je donio ocjenu pravog stanja - razmještenost gradiva kod ustanova i pojedinaca te približni omjer sačuvanog i, nažalost, zagubljenog gradiva. Ujedno, obilježavanje obljetnice bilo je prigoda da sažimajući činjenice kroz presjek povijesti Društva uz osnovni izvor - pripadajući arhiv - posegnemo i za drugima - „knjižničarem arhivistom“ i knjižnicom. Prvi i osnovni izvor jest arhiv Društva koji je u većem dijelu administrativan (spisi, isprave), a sadrži i izvješća za stručni tisak, medije, novinske isječke i audio-vizualne zapise. Drugom izvoru (pridodano gradivo) pristupili smo kako bismo donekle nadomjestili podatke sadržane u zagubljenom gradivu. Do njih se dolazilo na osnovi razgovora s kolegama (usmena predaja) i/ili uvidom $\mathrm{u}$ njihove osobne arhive/zbirke pisane i likovno-dokumentarne građe, radove $\mathrm{u}$ stručnim časopisima, dopisivanje, povelje, nagrade i priznanja, fotografije i ostalu efemernu građu (programi, plakati, letci, članske iskaznice). Treći izvor (dopunski) odnosi se na dokumente pohranjene u arhivima splitskih ustanova - najčešće knjižnica (Sveučilišne knjižnice u Splitu, Gradske knjižnice M. Marulića, Pravnog fakulteta), ali i društava s kojima je DKST surađivao (HKD). Spomenuto je pregledavanje arhiva i slaganje povijesti Društva na osnovi triju navedenih izvora 1999. rezultiralo izložbom Društvo knjižničara u Splitu u riječi i slici: 1949.1999. Sama likovno-dokumentarna građa bila je izložena kronološki i naslovljena: 1949.-1962. od povjereništva do podružnice DBH u Splitu ; 1963.-1974. iz djelatnosti podružnice; 1975.-1979. prve godine samostalnoga Društva bibliotekara u Splitu ; 1980.-1984. od plenuma do BIS-a ; 1985.-1989. od početaka kompjutorizacije do pokretanja glasnika Društva ; 1990.-1996. unatoč svemu aktivnosti se nastavljaju ; 1997.-1999. i to je sve ... do danas; Veseli kantun (knjižničarske

${ }^{21}$ Pravila su propisivala ustrojstvo, sastav članova te djelokrug i način poslovanja. Za sekcije, povjereništva i podružnice propisivani su posebni pravilnici. Podružnica Split primila je s materijalima godišnjih skupština DBH-a i izvještaje Nadzornog odbora koji su s vremenom donosili općenitije podatke, ne naznačavajući posebno stanje arhivskog gradiva DBH-a. Vidi: Pravila Društva bibliotekara Hrvatske. [195?.], strojopis (Arhiv DKST).

22 Navodimo neka od izlaganja: Služba dokumentacije u javnoj upravi i arhivi; Kriteriji za izbor registratura koje arhivi moraju nadzirati i preuzimati njihovu građu. Usp. Arhiv DKST 11/1-64. 
zgode i nezgode s putovanjâ po Europi). S vremenom su ta obljetnička izložba i njezina popratna kronologija postale referentne za više kasnijih projekata, podigle svijest o djelovanju Društva, ali i upozorile na važnost stvaranja, sređivanja, vrednovanja, akvizicijske politike i čuvanja pripadajućeg arhivskog gradiva. ${ }^{23}$ Tom prilikom stvoreni repozitorij raznovrsnog gradiva - izvornog ili presnimljenog iz navedenih izvora - korišten je u narednim godinama i u druge svrhe: sastavljanje kronologije djelovanja, izložbe, stručni skupovi, nakladnička djelatnost - Spomenica i sl. Iskustva stečena razgovorom i posudbom građe od članova u svrhu izrade preslika osvijestila su potrebu da se ubuduće o takvim privatnim arhivima razmišlja kao o važnom izvoru koji može dodatno obogatiti sam arhiv Društva, što će u nastavku biti detaljnije razrađeno. U vezi s time, želeći usvojiti primjere dobre prakse, ali i izvući pouku iz propusta, razmotrit će se nekoliko čimbenika: prostor pohrane, sadržaj i upravljanje, nereguliranost primopredaje i, naposljetku, pitanje javne dostupnosti gradiva. Prvi čimbenik - nedostatak vlastitog prostora za rad jedna je od važnih zajedničkih odlika većine knjižničarskih udruga u Hrvatskoj, pa tako i DKST-a. Utječe na sređivanje, dostupnost i pohranu gradiva. ${ }^{24}$ Stoga se, svjesna važnosti arhivskog gradiva, uprava Društva još 1979./1980. obratila splitskom SIZ-u u oblasti kulture za pomoć riječima: „Društvo nema svojih prostorija pa sastanke održava u Naučnoj ili nekoj drugoj biblioteci. Tako je i dokumentacija razasuta na nekoliko punktova [po raznim bibliotekama] što otežava normalan rad. Da bi se bar dokumentacija sačuvala i objedinila potrebno je nabaviti 1 ormar. “25 Nažalost, taj jedini do sada dokumentirani pokušaj uprave da očuva cjelovitost arhiva Društva (do 2004.) zbog izostanka sredstava ostao je nerealiziran i, možda, bio uzrok gubitku/zagubljenosti dijela gradiva, o čemu će nešto više riječi

23 Miolin, G. Društvo knjižničara u Splitu : kronologija razvoja i djelovanja 1949.-1999. [Split : DKST, 1999]. Izložba: Društvo knjižničara u Splitu u riječi i slici : 1949. - 1999. (Split, Pučko otvoreno učilište, listopad 1999.). Uz navedenu građu bili su izloženi izabrani radovi članova te njihove povelje, nagrade i priznanja posuđena za ovu priliku. Vidi i: Miolin, G. Posterska izlaganja članova Društva knjižničara u Splitu (1998.-2014.). Split: DKST, 2014.

24 Navedena ograničenja, u prvom redu prostorna, zasigurno su razlog zbog kojega je arhivsko gradivo mnogih knjižničarskih društava u Hrvatskoj slabije očuvano, a podaci nedostatni. Ta pojava ima za posljedicu primjerice nemogućnost utvrđivanja broja održanih skupština društava - izbornih i redovnih - kako DKST-a tako i DK Bilogore, Podravine i Kalničkog prigorja. Usp. Društvo knjižničara Bilogore, Podravine i Kalničkog prigorja. [citirano: 2018-06-06]. Dostupno na: http://www.drustvo-knjiznicara-bpkp.hr/40-godina-drustva-knjiznicara-bilogore-podravine-i-kalnickog-prigorja/. S navedenim problemom susrelo se 2005. i DK Slavonije i Baranje pripremajući izložbu Naših 30 godina te Spomenice Društva. Vidi: Spomenica Društva knjižničara Slavonije i Baranje: 1975.-2005. / ur. Marina Vinaj. Osijek: [DKSB], 2009. Podsjećamo da je DK Zadar pohranilo pripadajući arhiv u Državnom arhivu Zadar.

${ }^{25}$ U rukopisnom konceptu te zamolbe kancelarijski je ormar za pohranu arhive Društva trebao biti smješten u Naučnoj biblioteci (današnja SKS). Prema tadašnjem pojašnjenju, Društvo nije uspijevalo osigurati tražene financijske podrške SIZ-a jer nije bilo razvrstano ni u amaterska ni u ostala društva, pa je preduvjet bila izmjena Statuta. Usp. Arhiv DKST. Plan rada Društvo bibliotekara u Splitu za 1979. i 1980. 
biti kasnije. Usto, do 2000-ih su promjene sjedišta/adrese Društva s ustanovom/ knjižnicom novoizabranog predsjednika dodatno otežavale poslovanje.

Drugi čimbenik - upravljanje registraturnim gradivom i stvaranje arhivskog gradiva -ovisio je o djelovanju aktualnog predsjednika i tajnika, a ne za tu svrhu zaposlene osobe. Prema zatečenom stanju arhivskog gradiva Društva, možemo reći da je od 1950-ih, uz usvojene obrasce i standarde, dokumentiranje njegova rada bilo među knjižničarima uvriježeno, iako donekle neujednačeno. Za dio gradiva nije sačuvan ekvivalent u knjizi urudžbe, a jedina sačuvana jest ona vođena od 1980-ih do 2010. Po isteku mandata svojeg prethodnika preuzimao ju je novi predsjednik Društva, dok sam postupak nije jamčio pohranu i čuvanje gradiva koje je ostajalo u nekoj od knjižnica ili je, najčešće, zadržavano kod bivšeg predsjednika, što se pokušalo prevladati nabavkom „kancelarijskog ormara“, o čemu je već bilo govora. Treći čimbenik, do danas možda presudan, bilo je nepostojanje dokumenta ili/i odredbe ugrađene $u$ dokument koja bi regulirala primopredaju arhivskog gradiva po isteku mandata. Naime izvješća Nadzornog odbora o radu Glavnog odbora propisana Statutom društva, iznesena na izbornim i redovnim skupštinama, često nisu uzimala u obzir svu složenost tog segmenta poslovanja. Sagledavanje učinaka navedenih nedostataka na cjelovitost arhivskog gradiva od gubitka jednog njegova dijela i slabe zastupljenosti likovno-dokumentarne građe do, općenito, nedokumentiranosti rada članova Društva 2004. - rezultiralo je pojavom nekoliko inicijativa. Poziv upućen prijašnjim predsjednicima Društva i kolegama da se u Sveučilišnoj knjižnici u Splitu (SKS) na Odjelu specijalnih zbirki objedini sačuvana arhiva oživio je raniju misao o Naučnoj biblioteci kao mjestu njegove pohrane i donio rezultat. Uz dio gradiva koji je otprije zaostao u SKS-u, Gradskoj knjižnici M. Marulića te kod prijašnjih predsjednika, do 2005. prikupljeno je slijedeće gradivo: od 1949. do 2004., s tim da i dalje nedostaje razdoblje od god. 1966. do 1974. ${ }^{26}$ Dvostruki status SKS-a u odnosu na Društvo osnažen je odlukama Skupštine: 2008. kao mjesta pohrane arhive, a potom 2010. i kao njegova sjedišta. ${ }^{27}$ Godine 2015., usklađujući Statut DKST-a sa Zakonom o udrugama, skupština je usvojila prijedlog kojim se u slučaju prestanka postojanja udruge odlukom nadležnog tijela uprave, na prijedlog likvidatora, preostala imovina, a time i njegova arhiva, predaje ovoj knjižnici. ${ }^{28}$

26 Objedinjeno gradivo arhiva Društva preneseno je u cijelosti pri preseljenju knjižnice 2009. s adrese Zagrebačka 3 na adresu R. Boškovića 31 i pohranjeno na Odjelu specijalnih zbirki gdje se do danas nalazi. Vidi: Arhiv DKST. Izvještaj o radu Društva (listopad 2006. - lipanj 2008.); Zapisnik Izborne skupštine (19. 6. 2008); Zapisnik sastanka Glavnog odbora Društva (25. 10. 2006.). ${ }^{27}$ Arhiv DKST. Zapisnik Izborne skupštine 19. 6. 2008. i 10. 12. 2010.; Zamolba ravnatelju SKS-a Petru Kroli (30. 11. 2010.).

28 Slično tomu, i DK Istre Statutom predviđa da se arhiva Društva u slučaju prestanka rada predaje na čuvanje Sveučilišnoj knjižnici u Puli. Usp. Društvo bibliotekara Istre. Statut i pravilnici. [citirano: 2018-06-06]. Dostupno na: http://dbi.hr/statut-drustva/. Iz navedenog zaključujemo kako su u Hrvatskoj nacionalna i regionalne knjižničarske udruge sklonije svoju arhivu pohranjivati u većim knjižnicama - Nacionalnoj i sveučilišnoj i/ili sveučilišnim, dok primjerice Hrvatsko mu- 
Nadalje, zadužena je osoba koja je u određenom mandatu sustavno brinula o vizualnom dokumentiranju svih važnijih događanja u Društvu. Po objedinjavanju arhive na Odjelu specijalnih zbirki SKS-a načinjen je plan sređivanja gradiva koje je razvrstano kronološki, u serije i podserije. Pohranjeno je u 15 arhivskih kutija, uz sumarni inventar. Sadržaj najvećeg dijela dokumenata odnosi se na rad upravnog tijela (Glavnog odbora): pozivi, zapisnici, dopisivanje, edukacije i sl ${ }^{29}$ Dio je vezan uz nakladništvo omeđenih publikacija i Glasnik Društva bibliotekara Split te rad uredništva mrežnih stranica. Tu su i pristupnice članova, uplatnice članarina, programi stručnih putovanja, financije općenito te promotivni materijali vezani uz projekt Informacije o EU u narodnim knjižnicama (2004.-2006.). ${ }^{30}$

\subsubsection{Od arhiva knjižničara do arhiva udruge}

Važnost i najmanjeg dijela arhivskog gradiva za knjižničarsku udrugu općenito slikovito opisuje Daniela Živković nakon što je tek nekoliko naknadno nađenih dokumenata promijenilo „kroniku knjižničarske struke“ i djelovanja nacionalne knjižničarske udruge. Zapisala je tada:

„Listajući požutjele spise nailazimo na kamene međaše knjižničarstva. Oni su svjedoci početaka rada Društva čije je članstvo doduše bilo malobrojno. Presudno je bilo da su se tada u društvu okupili i udružili svoje znanje ljudi sa već zrelim, oblikovanim pogledima na knjižničarstvo kao struku, znali kako je treba razvijati i tražili u tome nove suradnike diljem Hrvatske. Zahvaljujući njima stvoreni su temelji za kasniji razvoj suvremenih područja knjižničarstva“"31

\footnotetext{
zejsko društvo i Hrvatsko arhivističko društvo u svojim statutima imaju stavak koji predviđa da se u slučaju prestanka rada udruge imovina, dakle spisi i drugo arhivsko gradivo, ustupa HDA-u. Vidi: Lučić, M. Nav. dj., str. 65.

${ }^{29}$ Za dokumentiranje rada Društva slikovito je zapažanje iz izvještaja o radu za razdoblje 1979./1981.: „Izvršni odbor (...) sastao se 12 puta, no to je samo onaj dio koji je ostao dokumentiran. U vrijeme kada telefon postaje uobičajeno sredstvo komuniciranja, rad i dogovori IO najčešće se tako i odvijao, kako u radno vrijeme tako i u poslijepodnevnim časovima." Vidi: Arhiv DKST. Izvještaj o radu DBS (br. 19/1981).

30 U arhivi Društva pohranjen je i komplet Glasnika od br. 1 do br. 12/13. U vezi s članstvom napomenimo kako su prve ,pristupnice za individualne i kolektivne članove“ Društva poslane 1978., a trebale su poslužiti zasnivanju kartoteke. Tomu je prethodio upit INDOK-službe Zavoda za kulturu Hrvatske krajem 1978. o članstvu (broj, zanimanje i stručna sprema, djelatnost društva) u svrhu ažuriranja podataka o stručnim društvima i udruženjima za Statističko-informativni pregleda u kulturi SR Hrvatske uz obrazloženje da pri HKD-u ne postoji evidencija o članstvu i djelatnostima za područje Hrvatske u cjelini. Vidi: Arhiv DKST. Zapisnik sastanka DBS (br. 9 i 50/1979.).

31 Živković, D. Osnutak i prve godine rada: pogled u arhivu. // Hrvatsko knjižničarsko društvo: 14. III. 1940. - 14. III. 2000.: spomenica. Zagreb: Hrvatsko knjižničarsko društvo, 2000. Str. 16. Podsjetimo da se 1940. sekcija Zagreb, tada dio Društva jugoslavenskih bibliotekara, izdvojila u samostalnu udrugu - Hrvatsko bibliotekarsko društvo (HBD). Dokumenti o njegovu djelovanju pronađeni su tijekom priprema za selidbu građe iz zgrade NSK-a na Marulićevu trgu 12 u novu
} 
Nije li taj zapis dovoljan da knjižničarske udruge kao imperativ postave sustavno vođenje i brigu o pohrani arhivskog gradiva? Preduvjet je to i za obogaćivanje sadržaja arhiva pridodanim gradivom iz privatne arhive/zbirke članova Društva po utvrđenim kriterijima. Stoga, nasljeđujući od prethodnika usvojena načela upravljanja gradivom (sređivanje, odabiranje i vrednovanje), moguće je, uz uvođenje novih tehnoloških modela, stvarati arhivu bez nepotrebnog gomilanja do pohrane na za to određeno mjesto. Iako su se tehnike dokumentiranja/izvora tijekom vremena mijenjale te je analogan način danas gotovo u potpunosti zamijenjen digitalnim, cilj je ostao isti - djelovati i ostvarivati poslanje struke u društvu, ali i ostaviti trag o tom djelovanju. On ovisi o nama samima jer udruga knjižničara kao privatni stvaratelj ima mogućnost vrednovanjem sadržaja i primjerenim oblicima čuvanja, u vlastitom interesu, stvarati arhivsko gradivo. Sam proces i kriteriji vrednovanja često su prijeporni i u arhivističkoj struci. Stoga treba imati na umu misao kanadskog arhivista Terrya Cooka: „Mi smo ono što ne čuvamo, što svjesno odstranjujemo, marginaliziramo, ignoriramo i uništavamo. ${ }^{\text {"32 }} \mathrm{Uz}$ već opisanu strukturu arhivskog gradiva Društva, koje najvećim dijelom sadrži administrativno gradivo, u nastavku će se rada razmotriti mogućnost pridruživanja privatne dokumentacije njegovih članova. Opravdanje tom prijedlogu nalazimo u iskustvima stečenim aktivnim djelovanjem u Društvu. Naime s nedovoljnim poznavanjem rada kolega i manjkavim podacima susrećemo se pri obilježavanju obljetnica te uređivanju rubrike o umirovljenim ili umrlim članovima u Glasniku Društva bibliotekara $u$ Splitu. Smjenu generacija knjižničara u Društvu i knjižnicama neminovno prate i zakonitosti promjena: od knjižničnog poslovanja, oblika edukacije i razmjene informacija te napredovanja u struci, pa do odnosa, senzibiliteta, atmosfere, planova i dosega. Budući da je i u samom poslanju Društva naznačeno održavanje dobrih odnosa i uvažavanje članova tijekom aktivnog članstva, ali i poslije, treba na vrijeme stvoriti preduvjete za sustavno i promišljeno pridruživanje privatne dokumentacije članova cjelini arhivskog gradiva Društva. Sadržajna raznolikost privatne dokumentacije ovisi o njihovim stvarateljima. Jedni su tako stvorili gradivo koje dokumentira osobno djelovanje: više ili manje bogate bibliografije, teorijski prinos struci, dopisivanje s brojnim suradnicima, priznanja, projekte, neobjavljene radove i sl. Drugi su unaprijedili radne procese ili pak, ne manje važno, dali osobni pečat djelovanju Društva ili knjižnice matične ustanove u određenom vremenu. Iako je donekle moguće veći dio tih informacija rekonstruirati, vrijedi ih osvijestiti, prikupiti, zabilježiti i sačuvati. U konačnici, nastale u određenom vremenskom kontekstu, one su prinos obuhvatnijem dokumentiranju knjižničarske struke na

zgradu (omotnica s dokumentima i otisnutim prvim žigom HBD, 22 pristupnice i popis članova - redovitih i izvanrednih). Autorica spominje Zapisnik o primopredaji imovine bivšega HBD-a novoosnovanom DBH-u od 25. 1. 1949. Ministarstvo unutarnjih poslova NR Hrvatske odobrilo je 30. 12. 1948. rad udruge knjižničara DBH.

32 Cook, T. „Mi smo ono što čuvamo; čuvamo ono što jesmo“: prošlost, sadašnjost i budućnost arhivističkog vrednovanja. // Arhivski vjesnik 56 (2013), str. 11. 
području djelovanja udruge, ali i šire od toga. U tu bi svrhu knjižničarska udruga trebala sustavno educirati, poticati, navikavati, ali i graditi povjerenje kako bi članovi, uz određene uvjete, stečeno radno iskustvo zabilježili i/ili likovno-dokumentarnu građu, dopisivanje i sl. pohranili u arhivu. ${ }^{33} \mathrm{U}$ samome Društvu brigu o dokumentiranju rada članova moguće je povjeriti primjerice radnoj grupi ili osobi koja za to posjeduje sklonost i stručnu sposobnost. Preuzimanje privatnog arhivskog gradiva (dokumenata ili dokumentacijske cjeline) može se ostvariti darom, otkupom ili pohranom. O primitku gradiva Društvo bi izdalo potvrdu s naznakom svrhe i programa u koji će se donacija koristiti, pismo zahvale, formalni darovni ugovor ili neku drugu potvrdu koju zatraži darovatelj. ${ }^{34} \mathrm{O}$ istome bi se trebala voditi i odgovarajuća evidencija u vidu svojevrsne knjige akvizicija. Promišljanje o „knjižničaru arhivistu“ ima uporište i u smjernicama hrvatske arhivističke teorije koja, oslanjajući se na međunarodnu praksu, navodi model specijaliziranih arhiva koji kroz osobne fondove znanstvenika, osim preko objavljenih radova, prate razvoj znanosti i preko šireg područja njihova djelovanja - društvenog, kulturnog i sl. Unatoč činjenici da ti arhivi u Hrvatskoj još nisu zaživjeli, arhivisti nastavljaju razvijati ideju sveobuhvatnog arhiva kako bi povijesni razvoj nekoga područja ili zajednice cjelovito dokumentirali, bez obzira na vrstu i oblik zapisa te provenijenciju. ${ }^{35}$ Pritom značajno mjesto zauzima „građanin arhivist“ i njegova privatna arhiva koja se kao izvor informacija s vremenom iz tradicionalnog/analognog preoblikovala u elektronički oblik: baze podataka, elektroničke kopije dokumenata i drugih elektroničkih zapisa nastalih u poslovanju, elektroničku poštu, oglašavanje na raznim društvenim mrežama, blogovima i sl. ${ }^{36}$

Stoga prilikom planiranja prikupljanja i pohrane tekućeg ili pridodanog arhivskog gradiva DKS-a tu činjenicu treba imati u vidu. U navedenoj ideji „sveobuhvatnog arhiva“ knjižničarska zajednica zasigurno ima svoje mjesto, a

33 Švenda Radeljak u navedenoj doktorskoj radnji piše o radu članica DKST-a: Nede Anzulović, Ane Bašić i Dubravke Bošnjak. Vidi: Švenda Radeljak. Nav. dj., str. 186, 208 i 213. Inače, autorica zaključuje kako su stereotipi o tipično muškim, odnosno ženskim zanimanjima zapravo razlog određenog stupnja marginaliziranosti profesija poput knjižničarstva i sličnih.

34 Darovi za zbirke: smjernice za knjižnice. // Darovi za zbirke: smjernice za knjižnice. Upute za izradbu smjernica za izgradnju knjižnične zbirke primjenom modela Conspectus. Međunarodna posudba i dostava dokumenata : načela i smjernice za postupanje. Model nacionalnog pravilnika za međuknjižničnu posudbu / prevele J. Leščić, Z. Majstorović, V. Golubović. Zagreb: Hrvatsko knjižničarsko društvo, 2010. Str. 13, 26.; Hebrang Grgić, I. Dar kao način izgradnje zbirki u hrvatskim narodnim knjižnicama. // Vjesnik bibliotekara Hrvatske 54, 3 (2011), str. 98, 99.

35 Lučić, M. Osobni arhivski fondovi: arhivistički pogled na prikupljanje, obradbu i interpretaciju rukopisnih ostavština u baštinskim institucijama. Zagreb: Hrvatski državni arhiv, 2014. Str. 41, 42, 88. U knjižničarskoj praksi npr. arhiva knjižničarke Elze Kučera (1883.-1972.) pohranjena je u Nacionalnoj i sveučilišnoj knjižnici (Obiteljski i osobni dokumenti (1832-1956)), a Tatjane Blažeković (1918.-2011.) u Sveučilišnoj knjižnici u Rijeci.

36 Pavelin, G. Donatori kao ciljana skupina komunikacijskih aktivnosti arhiva. // Medianali (2014), 1-28. [citirano: 2018-06-06]. Dostupno na: https://www.bib.irb.hr/pregled/znanstvenici/324173. O zaštiti elektroničkih zapisa vidi i: Pravni okvir. Nav. dj., str. 17. 
arhivističke i informatičke službe jedno od mogućih područja za razvijanje partnerskih odnosa.

\section{Međunarodna iskustva}

Potvrdu prethodno iznesenih promišljanja o arhivima knjižničarskih udruga u Hrvatskoj nalazimo u međunarodnoj praksi. Stoga iznosimo nekoliko iskustava - jedno anglosaksonskih knjižničara (SAD i UK), a drugo iz nama susjedne Italije, koja, uz različitosti proizašle iz društvenih prilika tijekom djelovanja od 1920-ih do danas, posjeduje zajedničku odliku - povezivanje gradiva knjižničarske zajednice svojih zemalja bez obzira na nosioca informacije na jednom mjestu. Slikovit je primjer American Library Association (ALA) - najstarije i najveće nacionalno udruženje knjižničara na svijetu koje danas okuplja oko 60 000 članova. Arhiv udruge American Library Association Archives osnovan je 1973. godine, kada je ALA sklopila ugovor sa Sveučilištem Urbana-Champaign u Illinoisu kako bi osigurala trajno dostupan pregled svog djelovanja. Arhivsko gradivo ALA-e uglavnom datira od 1920-ih do danas. ALA-in institucionalni repozitorij - The American Library Association Institutional Repository (ALAIR) - digitalni je repozitorij u otvorenom pristupu. ${ }^{37}$ Služi za prikupljanje, trajno pohranjivanje i slobodan pristup publikacijama i ostalom gradivu koje se odnosi na organizacijsko i intelektualno djelovanje američkog knjižničarskog udruženja. Repozitorij je organiziran tako da odražava samu strukturu djelovanja ALA-e te sadrži arhivsku dokumentaciju koja se odnosi na rad odjela, ureda, odbora i okruglih stolova. Pored spomenute strukture, osoblje arhiva može na zahtjev članova udruge stvarati i posebne zbirke važnijih zapisnika, izvještaja, biltena ili konferencijskih materijala. ALA potiče svoje osoblje i aktivne članove da pohranjuju razne dokumente, statute, podzakonske akte, službene zapisnike i slično izravno u ALAIR, pružajući im za to odgovarajuću tehničku podršku. ${ }^{38} \mathrm{Od}$ uredske dokumentacije poželjni su razni službeni dopisi, memorandumi i drugo gradivo koje se odnosi na rad ureda. Isto tako, članove se upućuje da dostavljaju sve ključne dokumente ALA-e koji se odnose na razvojne politike i druge važne odluke, izjave i govore vezane uz određena događanja. Također se pohranjuju sve ALA-ine publikacije, brošure i plakati, a od audio-vizualnih sadržaja čuvaju se fotografije, zvučne snimke, filmovi i videozapisi. Arhiv najčešće koristi osoblje i članovi ALA-e, a zatim i povjesničari, profesori i studenti knjižničarstva i informacijskih znanosti, u svrhu raznovrsnih istraživanja, počevši od povijesti knjižnica i knjižničarstva, pa do vrednovanja uloge knjižničarskih društava u na-

37 The American Library Association Institutional Repository. [citirano: 2018-01-29]. Dostupno na: https://alair.ala.org/.

38 American Library Association Archives. [citirano: 2018-01-29]. Dostupno na: https://archives.library.illinois.edu/ala/alair/deposit/. 
cionalnim i međunarodnim događanjima. Spoznaju o značaju privatnih „arhiva“ u širem društvenom kontekstu i važnosti osobnih zbirki članova knjižničarskih društava za izgradnju institucionalnih arhiva u Hrvatskoj, iznesenu u prethodnom poglavlju, moguće je povezati s nezanemarivim značajem koji privatne arhive imaju pri stvaranju ALA-ina institucionalnog repozitorija. Štoviše, privatno je doniranje poželjno, a regulirano je smjernicama koje upućuju na to kako i što donirati. ${ }^{39}$ Pritom se prednost daje onoj osobnoj dokumentaciji članova koja se odnosi na rad ALA-e ili je u vezi s njezinim djelovanjem. Za doniranje ostale privatne građe članova koja nije u izravnoj vezi s radom ALA-e potrebno je zatražiti dodatno tumačenje od strane osoblja arhiva. Smjernice upućuju i na one materijale koji nisu prikladni za doniranje ALA-inu repozitoriju, kao što su zapisi o određenim financijskim transakcijama, duplikati, razni nacrti i bilješke kasnije javno objavljenih radova ${ }^{40}$ Posljednjih godina ALA putem različitih programa sustavno promovira važnost svojih arhiva i nastoji educirati članstvo da aktivno i odgovorno sudjeluje u izgradnji institucionalnog repozitorija. U tom je smislu 2016. za programske potrebe ALA-ina okruglog stola Map and Geospatial Information Round Table kreiran i videozapis pod nazivom ALAIR: Why \& How, koji govori o važnosti čuvanja dokumentacije i poziva članstvo na pravilno deponiranje dokumenata $u$ institucionalni repozitorij. ${ }^{41} \mathrm{I}$ na drugim stručnim skupovima i godišnjim konferencijama američkih knjižničara sve se češće govori o važnosti čuvanja dokumentacije i značaju arhivske građe ne samo za razvoj ALA-e već i za strateško promišljanje budućeg razvoja ukupne knjižničarske profesije u nacionalnim i međunarodnim okvirima. S tim u vezi spomenimo kako se posljednjih godina u knjižničarskoj teoriji sve više koristi pojam odgovorno knjižničarstvo kao važna odrednica modernog knjižničarstva 21. stoljeća, a počiva na tezi da je uloga naše struke ne samo pružati informacije korisnicima već i aktivno sudjelovati u svakodnevnom životu svoje zajednice doprinoseći tako socijalnoj pravdi i održivom razvoju kao globalnim ciljevima današnjice na svim razinama. Upravo u tom smjeru mijenja se i odnos prema arhivskom gradivu, čija vrijednost ima sve veći značaj u zagovaračkom smislu. Ako knjižnice i knjižničarska udruženja širom svijeta nastoje prilagoditi svoje usluge potrebama zajednice kojoj služe, onda su na isti način dužne ostaviti trag o svojim postignućima na temelju kojih mogu strateški promišljati buduće korake. Cijeli taj pristup „novom knjižničarstvu“, u čijem je fokusu društvena

39 Donate materials. // American Library Association Archives. [citirano: 2018-01-29]. Dostupno na: https://archives.library.illinois.edu/ala/donate-materials/.

40 Accessioning records: American Library Association archives at the University of Illinois at Urbana-Champaign. [citirano: 2018-06-06]. Dostupno na: https://archives.library.illinois.edu/ala/ files/2012/06/Accessioning-to-the-ALA-Archives.pdf.

41 ALAIR: why \& how. [citirano: 2018-01-29]. Dostupno na: https://archives.library.illinois.edu/ ala/alair/. 
zajednica, uključuje za knjižničare i obvezu oblikovanja narativa o toj istoj zajednici i ulozi knjižnica u njezinu razvoju. ${ }^{42}$

Poslanje srodno ALA-inu u Velikoj Britaniji ima strukovno udruženje knjižničara i informacijskih stručnjaka-CILIP: The Library and Information Association. To udruženje ima dugu tradiciju djelovanja, a organizirano je kroz više regionalnih mreža. CILIP (Chartered Institute of Library and Information Professionals) je formiran 2002. spajanjem udruženja Library Association (LA ili LAUK) osnovanog 1877. i udruge Institute of Information Scientist osnovane 1958. godine. ${ }^{43}$ Od 2017. djeluje pod nazivom CILIP: The Library and Information Association. Procjenjuje se da udruga danas broji 23000 članova. Ipak, CILIP-ovo arhivsko gradivo, kao potvrda njegova značaja za razvoj knjižničarske struke u Velikoj Britaniji, još uvijek, za razliku od ALA-ina, nije sustavno uređeno. CILIP Archives još su u nastajanju, a trenutno su na stranicama udruženja objavljene informacije o inicijativi Sjevernoistočne regionalne mreže članova - North Eastern Regional Members Network (NERMN) - koja čuva arhive vezane uz izdanja časopisa i rad odbora. ${ }^{44}$ Arhiv se trenutno sastoji od samo tri zbirke: North East CILIP (ili CILIP North East); North East Career Development Group i North Eastern Regional Members Network. Iako arhivi još nisu dostupni javnosti, određena je osoba za kontakt i iznalaze se načini za odgovarajuću pohranu arhivskog gradiva.

Iz prakse europskih knjižničarskih udruga navodimo još i zanimljiv primjer talijanskog nacionalnog udruženja Associazione Italiana Biblioteche (AIB). Udruga je osnovana 1930. godine, višegodišnja je članica IFLA-e i EBLIDA-e i aktivno je uključena u suvremena međunarodna kretanja u informacijsko-knjižničarskoj djelatnosti. AIB se sastoji od regionalnih sekcija podijeljenih po teritorijalnoj osnovi, a na mrežnim stranicama udruge AIB-WEB pod nazivom Materiali per la storia dei bibliotecari italiani formiran je digitalni arhiv udruge. ${ }^{45} \mathrm{Cilj}$ mu je učiniti javno dostupnim dokumente, slike i razne druge izvore koji se odnose na dugogodišnju djelatnost AIB-a, povijest knjižničara i povijest talijanskih knjižnica. Gradivo je strukturirano u sadržajne cjeline i podcjeline označene slovno i brojčano u svrhu bolje preglednosti i dostupnosti. Riječ je o posebno pripremljenu gradivu koje dijelom sadrže tekstove već dostupne u tiskanom obliku, kao i tekstove koji se nalaze na drugim lokacijama AIB-WEB-a. Digitalni arhiv također uključuje linkove koji upućuju na ostale relevantne izvore koji se nalaze na drugim sajtovima, a

42 Lankes, D. R. The new librarianship field guide. Cambridge, MA: MIT Press, 2015. Str. 185187.

${ }^{43}$ Chartered Institute of Library and Information Professionals. [citirano: 2018-01-29]. Dostupno na: https://www.revolvy.com/main/index.php?s=Chartered\%20Institute\%20of\%20Library\%20 and\%20Information\%20Professionals.

${ }^{44}$ CILIPArchives. [citirano: 2018-01-29]. Dostupno na: https://www.cilip.org.uk/members/group_content_view.asp?group $=200658 \&$ id $=678429$.

45 AIB-WEB. Materiali per la storia dei bibliotecari italiani. [citirano: 2018-01-29]. Dostupno na: http://www.aib.it/aib/stor/stor.htm. 
važni su za praćenje rada udruge. Na kraju, uspoređujući u danom kontekstu hrvatsku knjižničarsku praksu s navedenim međunarodnim iskustvima, javlja se misao kako bi prema američkom modelu suradnje nacionalnog knjižničarskog udruženja i znanstvene zajednice bilo moguće razmišljati o eventualnom partnerstvu HKD-a i Nacionalne i sveučlišne knjižnice u Zagrebu u svrhu otvaranja digitalnih arhiva/ repozitorija knjižničarskih udruga, članica Hrvatskog knjižničarskog društva.

\section{Zaključak}

Problematika arhivskog gradiva i arhiva strukovnih udruga kao njegovih privatnih stvaratelja i imatelja analizira se na konkretnom primjeru knjižničarske udruge. Iako je knjižničarskoj zajednici u Hrvatskoj briga o navedenom gradivu bliža negoli drugim udrugama raznih profila, tijekom proteklih desetljeća mnogo je toga bilo izloženo gubitku i uništenju. Za to postoje dva razloga: objektivne okolnosti - nedostatak prostornih i ljudskih resursa samih udruga, ali i arhivske službe - te nedovoljna svijest udruga o važnosti gradiva. Budući da u hrvatskoj AKM-zajednici imamo preduvjete za to da se stanje promijeni, poželjno je da regionalne knjižničarske udruge (HKD) potaknu suradnju s arhivskom strukom (HDA) kao savjetodavnom, edukacijskom i suradničkom strukom. Kao model propitivanja iskustava dobre i loše prakse upravljanja arhivskim gradivom knjižničarske udruge uzet je onaj Društva knjižničara u Splitu. Napominjemo, arhivsko je gradivo knjižničarskih udruga privatno, sadržaj mu je raznovrstan, a postupkom njegova vrednovanja izbjegava se gomilanje te se čuva unikatno i dokumentarno. Budući da knjižničarska društva u Hrvatskoj umjesto vlastitih prostora imaju samo sjedište u knjižnicama većih mjesta, poželjnije je gradivo pohraniti ovdje nego zadržavati ga kod fizičkih osoba. Teorijska polazišta ovoga rada, sagledana u cjelini, predstavljaju primjerenu podlogu za daljnje proučavanje problematike zaštite arhivskog gradiva knjižničarskih udruga kao dijela pisane baštine, imajući pritom u vidu nužnu sveobuhvatnost, standardiziranost i sustavnost. Iako su iznesene spoznaje korisne pri promišljanju o arhivskom gradivu određene knjižničarske udruge, dio njih moguće je, uz neke prilagodbe, primijeniti i na druge udruge. Time bi se stvorili preduvjeti za arhiv knjižničarske zajednice, jedinstven ne u fizičkom smislu, već u tematskom obuhvatu gradiva sustavno stvaranog i sačuvanog kod različitih stvaratelja i imatelja. Na kraju, zaključimo kako će bez cjelovitih arhiva regionalnih knjižničarskih udruga biti teško stvoriti pregled cjelokupnih aktivnosti i njihova značenja za zavičajnu zajednicu, ali i za hrvatsko knjižničarstvo u cjelini. 


\section{LITERATURA:}

Accessioning records: American Library Association archives at the University of Illinois at Urbana-Champaign. [citirano: 2018-06-06]. Dostupno na: https://archives. library.illinois.edu/ala/files/2012/06/Accessioning-to-the-ALA-Archives.pdf.

AIB-WEB. Materiali per la storia dei bibliotecari italiani. [citirano: 2018-01-29]. Dostupno na: http://www.aib.it/aib/stor/stor.htm.

American Library Association Archives. [citirano: 2018-01-29]. Dostupno na: https:// archives.library.illinois.edu/ala.

American Library Association Institutional Repository. [citirano: 2018-01-29]. Dostupno na: https://alair.ala.org/.

Anzulović, N. Iz pretpovijesti Hrvatskog knjižničarskog društva. // Spomenica Društva knjižničara u Splitu: 1950.-2010. // Glasnik Društva bibliotekara Split 8 (2010), $9-15$.

Arhiv DKST 1950. - 2010.

Bačić, E.; M. Kovačić; Ž. Siminiati Violić. Društvo knjižničara u Splitu: što smo bili i kamo idemo? // Vjesnik bibliotekara Hrvatske 58, 1/2 (2015), 241-262.

Chartered Institute of Library and Information Professionals. [citirano: 2018-01-29]. Dostupno na: https://www.revolvy.com/main/index.php?s=Chartered\%20Institute $\% 20$ of $\% 20$ Library\%20and\%20Information $\% 20$ Professionals.

CILIPArchives. [citirano: 2018-01-29] Dostupno na: https://www.cilip.org.uk/members/group_content_view.asp?group=200658\&id=678429.

Cook, T. „Mi smo ono što čuvamo; čuvamo ono što jesmo“: prošlost, sadašnjost i budućnost arhivističkog vrednovanja. // Arhivski vjesnik 56 (2013), 9-26.

Darovi za zbirke : smjernice za knjižnice. // Darovi za zbirke : smjernice za knjižnice. Upute za izradbu smjernica za izgradnju knjižnične zbirke primjenom modela Conspectus. Međunarodna posudba i dostava dokumenata : načela i smjernice za postupanje. Model nacionalnog pravilnika za međuknjižničnu posudbu / prevele J. Leščić, Z. Majstorović, V. Golubović. Zagreb : Hrvatsko knjižničarsko društvo, 2010. Str. 11-30.

Dokumenta: centar za suočavanje s prošlošću. [citirano: 2018-01-29]. Dostupno na: https://www.documenta.hr/en/zajedni\%C4\%8Dko-sje\%C4\%87anje.html.

Donate materials. // American Library Association Archives. [citirano: 2018-01-29]. Dostupno na: https://archives.library.illinois.edu/ala/donate-materials/.

Društvo bibliotekara Istre. Statut i pravilnici. [citirano: 2018-06-06]. Dostupno na: http://dbi.hr/statut-drustva/.

Društvo knjižničara Bilogore, Podravine i Kalničkog prigorja. [citirano: 2018-06-06]. Dostupno na: http://www.drustvo-knjiznicara-bpkp.hr/40-godina-drustva-knjiznicara-bilogore-podravine-i-kalnickog-prigorja/. 
Fistanić, B. Društvo bibliotekara Split. Zadar : [vlast. nakl.], 2011.

Hebrang Grgić, I. Dar kao način izgradnje zbirki u hrvatskim narodnim knjižnicama. // Vjesnik bibliotekara Hrvatske 54, 3(2011), 95-106.

Heđbeli, Ž. Privatno arhivsko gradivo. // Arhivski vjesnik 44 (2001), 93-101.

Lankes, D. R. The New librarianship field guide. Cambridge : MA: MIT Press, 2015.

Librarians as community partners: an outreach handbook / ed. C. Smallwood. Chicago: American Library Association, 2010. Str. 153-186.

Lučić, M. Arhiv i nevladine neprofitne organizacije: nadzor nad udrugama i akvizicijska politika. // Arhivski vjesnik 46, 1 (2003), 53-67.

Lučić, M. Osobni arhivski fondovi: arhivistički pogled na prikupljanje, obradbu i interpretaciju rukopisnih ostavština u baštinskim institucijama. Zagreb: Hrvatski državni arhiv, 2014.

Miolin, G. Društvo knjižničara u Splitu: kronologija razvoja i djelovanja 1949.-1999. [Split: DKST, 1999].

Pavelin, G. Donatori kao ciljana skupina komunikacijskih aktivnosti arhiva. // Medianali (2014), 1-28. [citirano: 2018-06-06]. Dostupno na: https://www.bib.irb.hr/pregled/znanstvenici/324173.

Petrović, Z. Bez udruga nestao bi balans oko različitih ideja u društvu. // Udruga: časopis za predsjednice/ke udruga i ostale odgovorne osobe u udrugama 23 (2016), 9.

Pravila Društva bibliotekara Hrvatske. [195?.], strojopis (Arhiv DKST).

Pravilnik o vrednovanju te postupku odabiranja i izlučivanja arhivskoga gradiva. // NN 90/2002. [citirano: 2018-06-08]. Dostupno na: https://narodne-novine.nn.hr/clanci/ sluzbeni/full/2002_07_90_1476.html.

Pravni okvir zaštite i obveze stvaratelja i imatelja arhivskog gradiva. // Stručni ispit za zaštitu i obradu arhivskog gradiva : priručnik. / ur. S. Babić. Zagreb: Hrvatski državni arhiv, 2010.

Pregled arhivskih fondova i zbirki Republike Hrvatske. Sv. 1. / ur. J. Kolanović. Zagreb : Hrvatski državni arhiv, 2006.

Spomenica Društva knjižničara Slavonije i Baranje: 1975. - 2005. / ur. Marina Vinaj. Osijek: [DKSB], 2009.

Švenda Radeljak, K. Obrazovanje i status knjižničara u Hrvatskoj do uvođenja studija bibliotekarstva : doktorski rad. Zagreb : [vlast. nakl.], 2012.

Opća deklaracija o arhivima. [citirano: 2018-01-29]. Dostupno na: http://www.arhiv. hr/Portals/0/Dokumenti/Statut/OP\%C4\%86A_DEKLARACIJA_O\%20ARHIVIMA_web.pdf?ver=2018-03-29-161544-913.

Upute za udruge stvaratelje arhivskog gradiva. [citirano: 2018-01-29]. Dostupno na: https://udruge.gov.hr/vijesti/upute-za-udruge-stvaratelje-arhivskog-gradiva/975. 
Uputstvo o vrednovanju registraturne građe. // Narodne novine 33/1987.

Državni arhiv u Splitu : vodič kroz arhivske fondove i zbirke $=$ Guidebook to the State archives Split = Guida ai fondi dell' Archivio di stato di Spalato / [prip. H. Mladineo Mika, N. Bajić-Žarko]. Split : Državni arhiv, 2009.

Zajedničko sjećanje. // Documenta. [citirano: 2018-01-29]. Dostupno na: https://www. documenta.hr/en/zajedni\%C4\%8Dko-sje\%C4\%87anje.html.

Zakon o arhivskom gradivu i arhivima: pročišćeni tekst zakona: NN 105/97, 64/00, 65/09, 125/11, 46/17. // Zakon.hr. [citirano: 2018-06-06]. Dostupno na: https://www. zakon.hr/z/373/Zakon-o-arhivskom-gradivu-i-arhivima.

Zakon o udrugama: pročišćeni tekst zakona: NN 74/14, 70/17. // Zakon.hr. [citirano: 2018-06-05]. Dostupno na: https://www.zakon.hr/z/64/Zakon-o-udrugama.

Zakon o udruženjima građana SR Hrvatske. // Narodne novine 26 (1973).

Zapisi nevladinih organizacija: zajedničko pamćenje: praktičan vodič u 60 pitanja / [prip. A. Le Goff ; prijevod Ž. Heđbeli]. Zagreb: Documenta - centar za suočavanje s prošlošću, 2006.

Živković, D. Osnutak i prve godine rada: pogled u arhivu. // Hrvatsko knjižničarsko društvo : 14. III. 1940. - 14. III. 2000. : spomenica. - Zagreb : Hrvatsko knjižničarsko društvo, 2000. Str. 9-16. 